\title{
Effect of Storage Time and Concentration of Used Cooking Oil on Polyhydroxyalkanoates (PHAs) Production by Cupriavidus necator $\mathrm{H} 16$ (Kesan Masa Penyimpanan dan Kepekatan Minyak Masak Terpakai Terhadap Pengeluaran Polihidroksyalkanoat melalui Cupriavidus necator $\mathrm{H} 16)$
}

\author{
CHATSUdA KONGPENG, JUTARUT IEWKITTAYAKORN \& WILAIWAN CHOTIGEAT*
}

\begin{abstract}
Polyhydroxyalkanoates (PHAs) can be used to replace petrochemical plastics in many applications. However, their production has limitation due to production cost. This research was conducted using alternative carbon source from waste to synthesize PHAs by Cupriavidus necator H16. In this study, PHAs were produced from used cooking oil (UCO) and compared with production PHAs from palm oil. Two UCO storage times (4 and 10 weeks) and three UCO concentrations $(10,20$ and $30 \mathrm{~g} / \mathrm{L})$ were used to determine the most optimum condition for PHA synthesis. The best optimum condition for PHA synthesis was cultivated in the medium containing $30 \mathrm{~g} / \mathrm{L}$ of UCO at 4 weeks storage. The cell dry weight (CDW) and PHA content were $5.26 \pm 0.61 \mathrm{~g} / \mathrm{L}$ and $27.36 \pm 2.04 \mathrm{wt} . \%$, respectively. These results were similar to cell cultivation using $20 \mathrm{~g} / \mathrm{L}$ palm oil and $1 \%$ of fructose $(5.93 \pm 0.33 \mathrm{~g} / \mathrm{L}$ of $\mathrm{CDW}$ and $26.96 \pm 6.14 \mathrm{wt}$. \% of PHA contents). In addition, PHA content from the culture with $10 \mathrm{~g} / \mathrm{L}$ of UCO stored for 10 weeks was higher than PHA content from the culture with 20 and $30 \mathrm{~g} / \mathrm{L}$ of UCO. Thus, it can be concluded that UCO could be used in PHA production.
\end{abstract}

Keywords: Bioplastics; Cupriavidus necator H16; polyhydroxyalkanoates (PHAs); used cooking oil (UCO)

\section{ABSTRAK}

Polihidroksialkanoat (PHA) boleh digunakan untuk menggantikan plastik petrokimia dalam kebanyakan aplikasi. Walau bagaimanapun, pengeluarannya mempunyai had kerana kos pengeluaran. Kajian ini dijalankan menggunakan sumber karbon alternatif daripada bahan buangan untuk mensintesis PHA menggunakan Cupriavidus necator H16. Dalam kajian ini, PHAs dihasilkan daripada minyak masak terpakai (UCO) dan dibandingkan dengan pengeluaran PHA daripada minyak sawit. Dua masa simpanan UCO (dua 4 dan 10 minggu) serta tiga kepekatan UCO (10, 20 dan $30 \mathrm{~g} / \mathrm{L}$ ) telah digunakan untuk menentukan syarat keadaan optimum untuk sintesis PHA. Keadaan optimum terbaik untuk sintesis PHA ialah dieram pada medium yang mengandungi $30 \mathrm{~g} / \mathrm{L}$ UCO pada 4 minggu penyimpanan. Berat sel kering (CDW) dan kandungan PHA masing-masing adalah 5.26 $\pm 0.61 \mathrm{~g} / \mathrm{L}$ dan 27.36 $\pm 2.04 \% \mathrm{bt}$. Keputusan ini adalah sama dengan penanaman sel menggunakan $20 \mathrm{~g} / \mathrm{L}$ minyak sawit dan $1 \%$ fruktosa $(5.93 \pm 0.33 \mathrm{~g} / \mathrm{L} \mathrm{CDW}$ dan $26.96 \pm 6.14 \%$ bt. kandungan PHA). Di samping itu, kandungan PHA daripada kultur dengan $10 \mathrm{~g} / \mathrm{L}$ UCO yang disimpan selama 10 minggu adalah lebih tinggi daripada kandungan PHA yang dikultur dengan 20 dan $30 \mathrm{~g} / \mathrm{L}$ UCO. Oleh itu, dapat disimpulkan bahawa UCO boleh digunakan dalam pengeluaran PHA.

Kata kunci: Bioplastik; minyak masak terpakai (UCO); Necator cupriavidus H16; polihidroksialkanoat (PHA)

\section{INTRODUCTION}

Polyhydroxyalkanoates (PHAs) are biopolymers that has gained widespread interest, since their properties are similar to petrochemical plastics (Bhubalan et al. 2011). They can be synthesized by a wide range of different grampositive and gram-negative bacteria. The gram-negative bacterium, Cupriavidus necator H16, formerly known as Alcaligenes eutrophus or Ralstonia eutropha, has generally been used as the production organism of choice due to intracellular accumulation of PHA of over $90 \%$ of the cell dry weight (Madison \& Huisman 1999).

In industrial production of PHAs, is limited by production cost. It is desirable to investigate inexpensive substrates that can produce high PHA content in order to make the production of PHAs economically more attractive
(Castilho et al. 2009; Chee et al. 2010). Several carbon sources ranging from inexpensive, effluents, wastewater to plant oils (Fukui \& Doi 1998), fatty acids (Eggink et al. 1992), alkanes (Lageveen et al. 1988) have been proposed to be capable substrates in the production of PHAs.

However, this study focussed on the use of used cooking oil (UCO) for the production of PHAs due to easily available waste in Southern Thailand. Fried chicken is one of the popular food leading to huge requirement of palm oil for frying process. Thus, the high volume of used cooking oil is being discharged from food processing industries. Large quality of UCO is often released to the environment or recycled in frying process, causing environment pollution and human life. It is also known that process during heat treatment of oils causes production of 
peroxides, compounds with relatively short carbon chain length (Verlinden et al. 2011) and free fatty acids (FFAs) (Mahesar et al. 2014). FFAs are more prone to oxidation and rancidity. The level of FFA depends on storage time, which are generally detrimental to flavor, color, odor and thus influence to usefulness of oil (Teoh 2002). It has been utilized in the biodiesel production (Cai et al. 2015), but it can be used in PHA production. The UCO was generally composed of unsaturated and saturated fatty acids such as 48\% linoleic acid (C18:2), 39\% oleic acid (C18:1) and palmitic (C16:0). Martino et al. (2014) reported that UCO can be used to produce amorphous polyhydroxy-butyrate granules from $C$. necator cells grown. While Verlinden et al. (2011) prove that saturated fatty acids from waste oil can lead to build-up of energy-rich PHB in bacteria. Utilizing these waste materials as carbon source for PHA production not only reduces the substrate cost, but also saves the cost of waste disposal. Fructose and oil palm are well known to be a proper carbon source for R. eutropha $\mathrm{H} 16$, but fructose is commonly considered as a drawback for the industrial application (Franz et al. 2010).

In this study, C. necator H16 (wild type) was used to synthesize PHAs by using UCO as its sole carbon source using two different UCO storage times ( 4 and 10 weeks) and three UCO concentrations (10, 20 and $30 \mathrm{~g} / \mathrm{L})$ to determine the most optimum condition for PHA synthesis compared with cultivation using fructose and oil palm.

\section{MATERIALS AND METHODS}

\section{BACTERIAL STRAIN AND CULTURE MEDIA}

Bacterial strain: Cupriavidus necator H16 was kindly provided by Professor Sudesh Kumar, USM (Universiti Sains Malaysia) was used in this study.

Culture media: Two culture media were used including nutrient-rich medium (NR) and mineral salts medium (MM). NR medium contained per liter of $2 \mathrm{~g}$ yeast extract, $10 \mathrm{~g}$ meat extract and $10 \mathrm{~g} / \mathrm{L}$ peptone. Meanwhile MM medium contained per liter of $2.8 \mathrm{~g} \mathrm{KH}_{2} \mathrm{PO}_{4}, 3.32 \mathrm{~g}$ $\mathrm{Na}_{2} \mathrm{HPO}_{4} \cdot 12 \mathrm{H}_{2} \mathrm{O}, 2 \mathrm{~g}$ urea, $1 \mathrm{~mL}$ of trace element solution (TE) and $0.23 \mathrm{~g} \mathrm{MgSO}_{4} \cdot 7 \mathrm{H}_{2} \mathrm{O}$. TE contained per liter of $\mathrm{HCl} 0.1 \mathrm{~N}$ solution: $0.22 \mathrm{~g} \mathrm{CoCl}_{2} \cdot 6 \mathrm{H}_{2} \mathrm{O}, 9.70 \mathrm{~g} \mathrm{FeCL}_{3}$, $7.80 \mathrm{~g} \mathrm{CaCl}_{3}, 0.12 \mathrm{~g} \mathrm{NiCl}_{2} \cdot 6 \mathrm{H}_{2} \mathrm{O}, 0.11 \mathrm{~g} \mathrm{CrCl}_{3} \cdot 6 \mathrm{H}_{2} \mathrm{O}$ and $0.16 \mathrm{~g} \mathrm{CuSO}_{4} \cdot 5 \mathrm{H}_{2} \mathrm{O}$ (Kek 2009). Before sterilization of the medium, the $\mathrm{pH}$ was adjusted to 7 using $\mathrm{NaOH}(1 \mathrm{~N})$. $\mathrm{MgSO}_{4} \cdot 7 \mathrm{H}_{2} \mathrm{O}$ was autoclaved separately and TE was also added aseptically to the MM medium after cooling. Carbon sources consisted of fructose, palm oil and used cooking oil. All oils were autoclaved separately before added to the culture medium.

\section{EXTRACTION OF POLYHYDROXYALKANOATES (PHAS) BY CHLOROFORM SOLVENT}

The PHA concentration was determined by gravimetric method (Dawes \& Senior 1973). Cultivation of bacteria in shake flasks was taken at a certain time interval and the culture was centrifuged $\left(8,000 \mathrm{rpm}, 10 \mathrm{~min}, 4^{\circ} \mathrm{C}\right)$ in a pre-weighed centrifuge tube. Cell pellets were centrifuged twice after washing with hexane and distilled water, respectively. The bacterial cells were completely dry in oven at $70^{\circ} \mathrm{C}$ followed by extraction using stirring in $1: 100$ $(\mathrm{g} / \mathrm{mL})$ of chloroform for $48 \mathrm{~h}$. The extract was passed through a filter $(0.22 \mu \mathrm{m})$. The filtrate was concentrated (using evaporator). The PHAs were precipitated and completely dried before its weight was finally determined. The polymer yields precipitated as a white substance.

\section{DETERMINATION OF FREE FATTY ACID (FFA) OF USED COOKING OIL}

Used cooking oil (UCO) was obtained from Kai Tod Decha restaurant, Hat Yai, Songkhla, Thailand - fried chicken restaurant. The UCO was filtered through normal sieve to remove food debris. UCO contains variables shelf life $(0$, 4 and 10 weeks).

Free fatty acid (FFA) of UCO was analyzed using titrimetric method (Oyem 2011). 5.0 g UCO sample was weighed into $250 \mathrm{~mL}$ conical flask and dissolved in $25 \mathrm{~mL}$ of isopropyl alcohol (IUPAC name propan-2-ol), followed by the addition 5 drop of $0.5 \%(\mathrm{w} / \mathrm{v})$ phenolphthalein in each sample. The sample was then titrated against $0.1 \mathrm{M}$ $\mathrm{NaOH}$ till the first pink coloured appears and was persistent for $30 \mathrm{~s}$.

The percentage of FFA value can be calculated from (1) (Oyem 2011):

$$
\text { Free fatty acids }(\mathrm{FFA}) \%=\mathrm{VmM} / 10 \mathrm{w} \text {, }
$$

where $\mathrm{V}$ is volume in millitres of sodium hydroxide; $\mathrm{m}$ is molarity of sodium hydroxide solution used; $\mathrm{M}$ is molecular weight of the FFA (oleic acid: 282); and $w$ is the weight in grams of samples.

\section{DETERMINATION OF GROWTH CURVE OF CUPRIAVIDUS NECATOR $\mathrm{H} 16$}

Starter cell of Cupriavidus necator H16 was grown in 250 $\mathrm{mL}$ flask containing $50 \mathrm{~mL}$ of NR medium for $22-24 \mathrm{~h}$ at $30^{\circ} \mathrm{C}$ until optical density (O.D.) $600 \mathrm{~nm}$ of cells reached to $3.5-4.0$, then $1.5 \mathrm{~mL}$ of the starter cell was transferred into $50 \mathrm{~mL}$ of MM medium in $250 \mathrm{~mL}$ flasks for PHA synthesis. Various carbon sources including 2\% fructose, $2 \%$ fructose and $20 \mathrm{~g} / \mathrm{L}$ of palm oil, $2 \%$ fructose and used cooking oils (10, 20 and $30 \mathrm{~g} / \mathrm{L})$ were added in MM medium to investigate growth curve. The flasks were incubated at $30^{\circ} \mathrm{C}$ in a rotary shaker at $200 \mathrm{rpm}$. The optical density (O.D.) of cells was measured using spectrophotometer UVVIS at the wavelength of $600 \mathrm{~nm}$ every $6 \mathrm{~h}$ until decrease in O.D. values were found. Cell culture was harvested by centrifuge method. The fermentation broth was centrifuged at $10,000 \mathrm{rpm}$ for $1 \mathrm{~min}$, then cell pellets were washed with hexane to remove unused oil and distilled water, respectively. 


\section{DETERMINATION EFFECT OF FRUCTOSE CONCENTRATION ON POLYHYDROXYALKANOATE SYNTHESIS}

$1.5 \mathrm{~mL}$ of the starter cell was transferred into $50 \mathrm{~mL}$ of MM medium in $250 \mathrm{~mL}$ flasks for PHA synthesis. Then, either a quantity of fructose with concentrations of 1 or $2 \%$ by volume were added to the MM medium containing $20 \mathrm{~g} / \mathrm{L}$ of oil palm. All flasks were incubated in a rotary incubator $(200 \mathrm{rpm})$ at $30^{\circ} \mathrm{C}$. All experiments were done in triplicate. The fermentation broth was centrifuged at $10,000 \mathrm{rpm}$ for $1 \mathrm{~min}$. Then the harvested cells were evaluated PHA content by chloroform solvent method. The optimum fructose concentration obtained from this study will be experimented in the part of using used cooking oil as carbon source.

\section{DETERMINATION EFFECT OF STORAGE TIME AND CONCENTRATION OF USED COOKING OIL ON PHA SYNTHESIS}

The starter cell $(1.5 \mathrm{~mL})$ was transferred into $50 \mathrm{~mL}$ of MM medium in $250 \mathrm{~mL}$ flasks for PHA synthesis. Then, a quantity of fructose with optimum concentration found earlier with $30 \mathrm{~g} / \mathrm{L}$ of used cooking oils stored for 4 and 10 weeks were added to the MM medium compared with addition of $20 \mathrm{~g} / \mathrm{L}$ of oil palm with optimum fructose concentrations. All flasks were incubated in a rotary incubator $(200 \mathrm{rpm})$ at $30^{\circ} \mathrm{C}$. All experiments were done in triplicate. The fermentation broth was centrifuged at $8000 \mathrm{rpm}$ for $20 \mathrm{~min}$. Then, the harvested cells were evaluated for PHA content by chloroform solvent method. The optimum storage time obtained from this study will be experimented in the part of using various concentrations $(10,20$ and $30 \mathrm{~g} / \mathrm{L})$ of used cooking oils.

\section{RESULTS AND DISCUSSION}

\section{FREE FATTY ACID (FFA) OF USED COOKING OIL}

The amount of FFA in used cooking oil (UCO) was stored for 0,4 and 10 weeks under light were $0.30,0.39$ and $0.58 \%$, respectively. The results indicated that the FFA of the UCO increased with increasing storage time corresponding to Oyem (2011). FFA is produced by the hydrolysis of oils via heat treatment process. FFA contained in the oil was oxidized under the influence of oxygen and storage time (Mahesar et al. 2014; Verlinden et al. 2011).

\section{GROWTH CURVES}

The growth curves of $C$. necator H16 cultivated in MM medium using various carbon source including $2 \%$ of fructose, $2 \%$ of fructose with $20 \mathrm{~g} / \mathrm{L}$ of palm oil and $2 \%$ of fructose with 10,20 and $30 \mathrm{~g} / \mathrm{L}$ of used cooking oil was shown in Figure 1. All results were done with three triplicates. Mean values and standard deviations are provided. The resulted noted that there are no different in trend of growth curves. The lag phases lasted until the $6 \mathrm{~h}$, the logarithmic phases from $6 \mathrm{~h}$ until $36 \mathrm{~h}$, the stationary phases from $36 \mathrm{~h}$ until $48 \mathrm{~h}$ and the death phase from $48 \mathrm{~h}$ hereafter. The growth curves dropped down at the end of stationary phase, possibly due to PHA degradation at death phase (Batcha et al. 2014). Thus, the logarithmic phase with $36 \mathrm{~h}$ of cultivation time was selected for further study.

\section{EFFECT OF FRUCTOSE CONCENTRATIONS ON POLYHYDROXYALKANOATE SYNTHESIS}

The effect of fructose concentration on PHA production is shown in Table 1. It was found that both carbon sources favored cell growth and PHA synthesis. However, it was noted that $C$. necator $\mathrm{H} 16$ cultivation with $20 \mathrm{~g} / \mathrm{L}$ palm oil with $1 \%$ added fructose gave higher PHAs content and lower dry cell weight than those with $20 \mathrm{~g} / \mathrm{L}$ palm oil with $2 \%$ fructose. It can be concluded that adding $2 \%$ of fructose are excess carbon source. It is possible that high fructose content can inhibit PHA synthesis. Thus, the fructose concentration with $1 \%$ by volume was selected to further study.

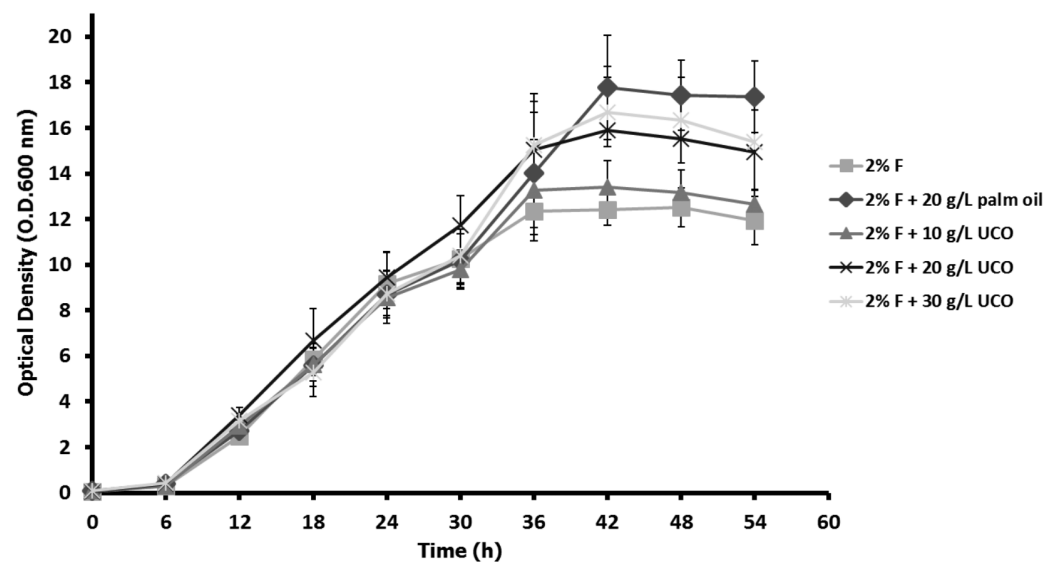

FIGURE 1 . The optical density (O.D.600)versus time of $C$. necator $\mathrm{H} 16$ cultivation in mineral medium using $2 \%$ of fructose, $2 \%$ of fructose with $20 \mathrm{~g} / \mathrm{L}$ of palm oil and $2 \%$ of fructose with 10,20 and $30 \mathrm{~g} / \mathrm{L}$ of used cooking oil 


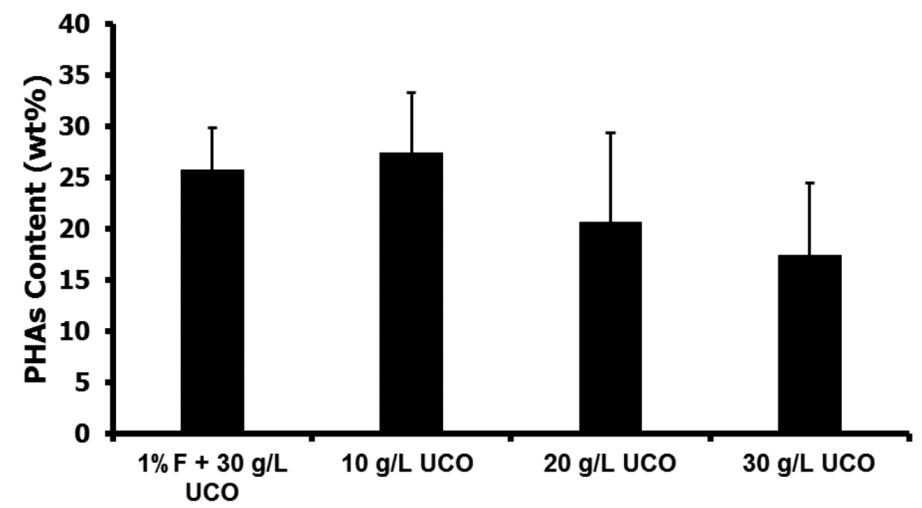

FIGURE 2. PHA contents obtained from cultivation with adding $10 \mathrm{~g} / \mathrm{L}, 20 \mathrm{~g} / \mathrm{L}$ and $30 \mathrm{~g} / \mathrm{L}$ of UCO at 10 weeks storage time

TABLE 1. Effect of different fructose concentrations on PHA production using C. necator H16

\begin{tabular}{lccc}
\hline Sugar source & $\begin{array}{c}\text { Dry cell weight } \\
(\mathrm{g} / \mathrm{L})\end{array}$ & $\begin{array}{c}\text { PHA content } \\
(\mathrm{wt} \%)\end{array}$ & $\begin{array}{c}\text { Total PHAs } \\
(\mathrm{g} / \mathrm{L})\end{array}$ \\
\hline Fructose $1 \%$ and $20 \mathrm{~g} / \mathrm{L}$ palm oil $(36 \mathrm{~h})$ & $4.7 \pm 1.6$ & $26.7 \pm 6.1$ & $1.6 \pm 0.5$ \\
Fructose $2 \%$ and $20 \mathrm{~g} / \mathrm{L}$ palm oil $(48 \mathrm{~h})$ & $7.2 \pm 1.4$ & $12.6 \pm 4.6$ & $0.6 \pm 0.2$ \\
\hline
\end{tabular}

\section{EFFECT OF STORAGE TIME AND CONCENTRATION OF USED COOKING OIL ON PHA SYNTHESIS}

Effect of storage times of used cooking oils on PHA synthesis are shown in Table 2. It was noted that the PHA content obtained from cultivation with adding 20 $\mathrm{g} / \mathrm{L}$ oil palm and $1 \%$ fructose gave similar results with those obtained from cultivation with adding $30 \mathrm{~g} / \mathrm{L}$ used cooking oil (UCO) with storage time for 4 weeks. This result can be concluded that storage time for 4 weeks and concentration of $30 \mathrm{~g} / \mathrm{L}$ was optimum condition to use UCO as carbon source instead of oil palm.

In addition, PHA content obtained from cultivation with adding $30 \mathrm{~g} / \mathrm{L}$ UCO stored for 4 weeks was higher than those obtained from cultivation at $30 \mathrm{~g} / \mathrm{L}$ UCO stored for 10 weeks. This may be resulted from free fatty acid (FFA) contained in UCO. FFA are feasible generally detrimental to bacterial cell, hypothesized that the formation of other oxidation products in UCO after repeated frying may be generally detrimental to the bacterial growth and subsequently the PHA synthesis (Kek 2009).

TABLE 2. Effect of storage time and carbon source of used cooking oil for PHA synthesis

\begin{tabular}{lc}
\hline Carbon source & $\begin{array}{c}\text { PHA content } \\
\text { (wt. \%) }\end{array}$ \\
\hline $1 \% \mathrm{~F}$ & $2.43 \pm 0.34$ \\
$1 \% \mathrm{~F}+20 \mathrm{~g} / \mathrm{L}$ palm oil & $26.96 \pm 6.14$ \\
$30 \mathrm{~g} / \mathrm{L}$ UCO stored for 4 weeks & $27.36 \pm 2.04$ \\
$30 \mathrm{~g} / \mathrm{L}$ UCO stored for 10 weeks & $17.45 \pm 7.07$ \\
\hline
\end{tabular}

$\mathrm{F}=$ fructose $\mathrm{UCO}=$ used cooking oil
Effect of concentration of UCO on PHA synthesis is shown in Figure 2. The UCO stored for 10 weeks was studied. The PHA contents obtained from cultivation with addition of 10, 20 and $30 \mathrm{~g} / \mathrm{L}$ of UCO were $27.45 \pm 5.89$, $20.65 \pm 8.78$ and $17.45 \pm 7.07$ wt. $\%$, respectively. This result showed that low concentration of UCO gave higher PHA content than those obtained from high concentration. High concentration of UCO stored for longer time may provide negative effect to bacterial. Moreover, it was observed that PHA contents obtained from cultivation with addition $10 \mathrm{~g} / \mathrm{L}$ UCO was similar to PHA content obtained from cultivation with addition of $30 \mathrm{~g} / \mathrm{L} \mathrm{UCO}$ add $1 \%$ fructose. It can be concluded that $10 \mathrm{~g} / \mathrm{L}$ UCO could support PHA production at long storage time.

\section{CONCLUSION}

Polyhydroxyalkanates produced from Cupriavidus necator $\mathrm{H} 16$ using $30 \mathrm{~g} / \mathrm{L}$ of used cooking oil (UCO) stored for 4 weeks gave similar result to cell cultivation with $20 \mathrm{~g} / \mathrm{L}$ palm oil and $1 \%$ of fructose. The cell dry weight and PHA content obtained from using UCO were 5.93 \pm 0.33 $\mathrm{g} / \mathrm{L}$ and $26.96 \pm 6.14$ wt. \%, respectively. Meanwhile, the cell dried weight and PHA content obtained from using oil palm were 5.26 $\pm 0.61 \mathrm{~g} / \mathrm{L}$ and $27.36 \pm 2.04 \mathrm{wt}$. $\%$, respectively. Thus, it can be concluded that used cooking oil (UCO) has good potential as carbon source in PHA production using $C$. necator $\mathrm{H} 16$. UCO with $30 \mathrm{~g} / \mathrm{L}$ of concentration and storage time for 4 weeks can be used as carbon source instead oil palm for PHA synthesis. In addition, using UCO stored for 10 weeks at low concentration gave higher PHA content than those obtained from high concentration. 


\section{ACKNOWLEDGEMENTS}

This study was supported by the Center of Excellence for Genomics \& Bioinformatics Research and Department of Molecular Biotechnology and Bioinformatics, Faculty of Science, Prince of Songkla University, Thailand.

\section{REFERENCES}

Batcha, A.F.M., Prasad, D.M.R., Khan, M.R. \& Abdullah, H. 2014. Biosynthesis of poly (3-hydroxybutyrate) (PHB) by Cupriavidus Necator H16 from Jatropha oil as carbon source. Bioprocess and Biosystems Engineering 37(5): 943-951.

Bhubalan, K., Chuah, J.A., Shozui, F., Brigham, C.J., Taguchi, S., Sinskey, A.J., Rha, C. \& Sudesh, K. 2011. Characterization of the highly active polyhydroxyalkanoate synthase of Chromobacterium Sp. Strain USM2. Applied and Environmental Microbiology 77(9): 2926-2933.

Cai, Z.Z., Wang, Y., Teng, Y.L., Chong, K.M., Wang, J.W., Zhang, J.W. \& Yang, D.P. 2015. A two-step biodiesel production process from waste cooking oil via recycling crude glycerol esterification catalyzed by alkali catalyst. Fuel Processing Technology 137: 186-193.

Castilho, L.R., Mitchell, D.A. \& Freire, D.M. 2009. Production of polyhydroxyalkanoates (PHAs) from waste materials and byproducts by submerged and solid-state fermentation. Bioresour. Technol. 100(23): 5996-6009.

Chee, J.Y., Yoga, S.S., Lau, N.S., Ling, S.C., Abed, R.M.M. \& Sudesh, K. 2010. Bacterially produced polyhydroxyalkanoate (PHA): Converting renewable resources into bioplastics. In Current Research, Technology and Education Topics in Applied Microbiology and Applied Biotechnology, edited by MendezVilas, A. Spain: Formatex Research Center. pp. 1395-1404.

Dawes, E.A. \& Senior. P.J. 1973. The role and regulation of energy reserve polymers in micro-organisms. Advances in Microbial Physiology 10: 135-266.

Eggink, G., van der Wal, H. Huijberts, G.N.M. \& de Waard, P. 1992. Oleic acid as a substrate for Poly-3-Hydroxyalkanoate formation in Alcaligenes eutrophus and Pseudomonas putida. Industrial Crops and Products 1(2-4): 157-163.

Franz, A., Rehner, R., Kienle, A. \& Hartmut, G. 2010. Growth and PHA production of wild-type Ralstonia eutropha $\mathrm{H} 16$ using glucose and fructose as single carbon substrates. www. researchgate.net/publication/45940713_Growth_and_PHA_ production_of_wild-type_Ralstonia_eutropha_H16_using glucose_and_fructose_as_single_carbon_substrates

Fukui, T. \& Doi, Y. 1998. Efficient production of polyhydroxyalkanoates from plant oils by Alcaligenes eutrophus and its recombinant strain. Applied Microbiology and Biotechnology 49(3): 333-336.

Kek, Y.K. 2009. Utilization of Palm Oil-Based by-Products and Waste as Feedstock for Polyhydroxyalkanoate Biosynthesis. Master of Science thesis (Unpublished).
Lageveen, R.G., Huisman, G.W., Preusting, H., Ketelaar, P., Eggink, G. \& Witholt, B. 1988. Formation of polyesters by Pseudomonas Oleovorans: Effect of substrates on formation and composition of poly- (R)-3-Hydroxy-alkanoates and poly- (R)3-hydroxyalkenoates. Applied and Environmental Microbiology 54(12): 2924-2932.

Madison, L.L. \& Huisman, G.W. 1999. Metabolic engineering of poly (3-hydroxyalkanoates): From DNA to plastic. Microbiology and Molecular Biology Reviews 63(1): 21-53.

Mahesar, S.A., Sherazi, S.T.H., Khaskheli, A.R., Kandhro, A.A \& Uddin, S. 2014. Analytical approaches for the assessment of free fatty acids in oils and fats. Analytical Methods 6 : 4956-4963.

Martino, L., Cruz, M.V., Scoma, A., Freitas, F., Bertin, L., Scandola, M. \& Reisb, M.A.M. 2014. Recovery of amorphous polyhydroxy-butyrate granules from Cupriavidus necator cells grown on used cooking oil. International Journal of Biological Macromolecules 71: 117-123.

Oyem, H.H. 2011. Monitoring the free fatty acid level of crude palm oil stored under light of different wavelenghts. American Journal of Food Technology 6(8): 701-704.

Teoh, C.H. 2002. The Palm Oil Industry in Malaysia: From Seed to Frying Pan. WWF Switzerland.

Verlinden, R.A.J., Hill, D.J., Kenward, M.A., Williams, C.D., Piotrowska-Seget, Z. \& Radecka, I.K. 2011. Production of Polyhydroxyalkanoates from waste frying oil by Cupriavidus necator. AMB Express 1: 11. doi:10.1186/2191-0855-1-11.

Chatsuda Kongpeng, Jutarut Iewkittayakorn \&

Wilaiwan Chotigeat*

Department of Molecular Biotechnology and Bioinformatics

Faculty of Science

Prince of Songkla University

Hat Yai, Songkhla 90112

Thailand

Wilaiwan Chotigeat*

Center of Excellent for Genomics \& Bioinformatics Research

Faculty of Science, Prince of Songkla University

Hat Yai, Songkhla 90112

Thailand

*Corresponding author; email: wilaiwan58@hotmail.com

Received: 31 August 2016

Accepted: 17 January 2017 